\title{
Towards an economic-geographical approach to the globalisation of the hotel industry
}

\begin{abstract}
In the field of economic geography the hotel industry is largely under-researched. Meanwhile, its worldwide development has reached the level whereby it can no longer be neglected by economic geographers if the tourism production system and, more generally, the globalisation of services, are to be understood. The argument of this paper is two-fold. First, it is contended that an economic-geographical approach to the hotel industry can significantly enhance our understanding of this important sub-sector of tourism. Although the paper recognises the useful insights into the internationalisation/globalisation of the hotel industry elaborated within management and business studies, it argues that they fall short of exploring the globalisation of the hotel sector in three important respects: the multi-actor nature of the hotel industry, the territorial embeddedness of hotel groups in host markets and the influence of expanding hotel groups on economic development. Given that these gaps are geographical in nature, the paper argues the case for the global production networks (GPN) approach as an effective theoretical platform from which they can be addressed. Second, it is argued that the hotel industry can serve as a good sectoral case through which our understanding of the globalisation of services can be advanced. Enhanced attention to business models of hotel groups is argued to be key to both of these advancements.
\end{abstract}

\section{Key words}

The international hotel industry

The globalisation of services

Global production networks

Business models

International hotel groups

The tourism production system

\section{Introduction}

Since the 1980s the service sector has been embraced by economic geographers much more seriously (Bryson 2001, Tickell 1999, 2001, 2002) and geographical work on services has continued to increase in profile. Nonetheless, for many service industries - especially those broadly referred to as 'consumer services' - an economic-geographical research agenda is still largely under-developed. Amongst the least studied consumer services is the international 
hotel industry - the main focus of this paper. The dearth of research on the hotel industry in economic geography reflects the overall neglect of tourism in many disciplines as frivolous and not as important as, for instance, manufacturing (Ioannides and Debbage 1998a, see also Butler 2012, Gibson 2008, Hall 2005). It is only recently that the situation has started to change and tourism-related research has become more popular amongst geographers. The literature reviews by Butler (2004) and Hall and Page (2006, 2009, 2012) that summarise the recent geographical contributions to the general understanding of tourism and its spatialities serve as evidence of this interest. However, given that they illustrate how diversified the engagement of geographers with tourism is, it is also necessary to recognise that geographical research on tourism suffers from a low level of theoretical cohesiveness (Page 1995). It is mainly for this reason that, according to Hall and Page (2009, p. 5), there is not one geography of tourism but a 'range of tourism geographies marked by differences not only in subject but also in philosophy, method [and] scale' (see also Butler 2012).

One 'tourism geography' where the progress has been particularly slow is the one practiced by economic geographers. The reviews by Butler (2004), Gibson $(2008,2009)$ and Hall and Page $(2006,2009$, 2012) expose clearly the relative dearth of economic-geographical research on tourism. The valuable contributions by Agarwal et al (2000), d'Hauteserre (2006), ErkuşÖztürk and Terhorst (2010), Judd (2006), Milne and Ateljevic (2001), Mosedale (2006, 2008), Papatheodorou (2003), Rogerson (2010, 2011a, 2011b, 2013) and Rogerson and Kotze (2011) have not managed to sufficiently fill this void (see Ioannides 2006 and Debbage and Ioannides 2012 for more comprehensive reviews). Thus, as Gibson (2009) argues, despite important advancements, the status of tourism research in economic geography has not changed much since Ioannides's (1995) and Ioannides and Debbage's (1998a) calls for bridging the gap between tourism research and mainstream economic geography.

The low level of interest in tourism in economic geography originates from the perception of consumer services as peripheral actors whose importance in creating wealth is less significant than that of manufacturing and producer services (Debbage and Daniels 1998, Ioannides and Debbage 1998a). Meanwhile, the role of tourism in the global economy has grown to the level whereby it should no longer be neglected by economic geographers if the tourism production system and, more generally, the globalisation of services are to be sufficiently understood. Indeed, the tourism production system has evolved into a complex ensemble of firms, markets and institutions (Britton 1991) which together constitute the world's largest industrial 
complex (Lundberg et al 1995). The fact that tourism employs 6\% of the global workforce and its contribution to the world GDP is on average 5\% (UNWTO 2010, see also Lew 2011) further supports this assertion.

Building upon Agarwal et al (2000), d'Hauteserre (2006), Erkuş-Öztürk and Terhorst (2010), Judd (2006) and Mosedale (2006, 2008) and thus aiming to address Ioannides's (1995) and Ioannides and Debbage's (1998a) calls, this paper focuses on the hotel industry - one of the most important and most global sub-sectors of tourism (Go and Pine 1995, Whitla et al 2007). Recognising the potential of economic geography to help elucidate the operations of tourist corporations and unravel the complexities of the tourism production system (Hall and Page 2009), the paper argues the case for an economic-geographical approach - namely that of global production networks (GPN) - to the globalisation of the hotel sector. In this respect, the paper follows Agarwal et al (2000, p. 242) who indicated that 'there is a need for sensitive application of economic geography theories to tourism to redress the impoverishment of the fragmented research field of the geography of tourism production'. Although the paper recognises the valuable insights into the internationalisation/globalisation of the hotel industry elaborated within management and business studies, it argues that they fall short of exploring all its important aspects. Specifically, three main research gaps can be identified: the multiactor nature of the hotel industry, the territorial embeddedness of hotel groups in host markets and the impact of expanding hotel groups on regional development. The paper argues that, if researched from an economic-geographical perspective, the hotel industry is a good sectoral case through which our understanding of the globalisation of services can be advanced.

The paper is structured as follows. To set the scene and to better understand the nature of the hotel industry and its globalisation, the following section reviews the key features of the hotel sector. The feature that is critical to this paper - the variety of business models evident in the industry - is elaborated in detail in the third section. Finally, the fourth section identifies three main gaps in the existing research on the internationalisation/globalisation of the hotel sector and argues the case for the GPN approach as an effective theoretical platform from which they can be tackled. The contribution to our understanding of the globalisation of services potentially made by economic-geographical research on the hotel industry is also discussed. In order to provide a starting point for further analyses, a stylised example of an international hotel group's global production network is also elaborated. 


\section{The key features of the international hotel industry}

Due to the fact that it caters for accommodation needs of tourists, the hotel sector is of crucial importance to the travel industry (Go and Pine 1995). In addition to its contribution to the world GDP, as a 'component of the transnational infrastructure' (Go and Pine 1995, p. 367) which, just like the whole tourism sector, facilitates the movement of people, ideas and capital (Reiser 2003), the international hotel industry also contributes to the global economy in qualitative terms. In return, globalisation processes such as the development of advanced transportation and the growing political and economic liberalisation, all of which stimulate the increase in tourist trips (from 25 million in 1950 to 880 million in 2009 and the estimated 1.6 billion in 2020; UNWTO 2010), offer the hotel sector new opportunities for expansion, thus constantly facilitating its globalisation in its own right (Go and Pine 1995).

What is normally referred to as the hotel industry actually consists of two segments - a large number of independent hotels (85\% of all hotels) and a comparably small number of branded hotels comprised by large hotel groups (15\%) (Euromonitor 2010a). Although the hotel industry is very fragmented, hotel groups account for as much as $52 \%$ of global sales and therefore play a dominant role in the industry overall (Euromonitor 2010a). A hotel group is a group of hotel chains which are controlled by a central management and function according to the same strategy and marketing policy (Włodarczyk 2003). A hotel chain is a group of hotels which operate under the same brand, maintain the same standards of service and have a uniform marketing policy (Littlejohn 2003, Włodarczyk 2003). A hotel chain can thus be a separate company or part of a larger group comprising several chains. A form of chain affiliation (a brand) is what distinguishes chained hotels from independent outlets. Table 1 presents the 30 largest hotel groups in the world. Although the table implies a strong dominance of American and Western European groups (15 and 11, respectively), the increasing strength of groups originating from China (the remaining four groups in the table) and, generally, from the Global South, should not be underestimated. The latter especially applies to Mexican (e.g. Grupo Posadas), South African (e.g. Protea Hospitality Corporation) and Indian (e.g. The Oberoi Group) hotel groups (Hotels 325’ 2011).

This paper focuses on those hotel companies that are transnational in their scope and hence can be called international hotel groups. In this respect, the internationalisation/globalisation of the hotel industry can be equated to the international expansion of hotel groups and the development of 'the international hotel sector'. There are six features of the hotel sector that 
are of importance for understanding its globalisation. Firstly, the hotel sector is extremely sensitive to fluctuations in demand and the various external political and economic forces that cannot be controlled by managers (Go and Pine 1995). Indeed, the Gulf War, the events of 11th September 2001, the outbreaks of SARS and swine flu in the 2000s and the recent financial crisis were all observed to have a serious impact on hotel performance globally (Euromonitor 2010b, Go and Pine 1995, Kowalczyk 2003, Mather and Todd 2002).

Secondly, despite the importance of external forces, the hotel industry is characterised by a strong 'localised focus' (Athiyaman and Go 2003, Go et al 1996). As Olsen and Merna (1993, p. 102) put it, 'the hospitality industry is unique in the fact that it does business on a very local level even though it may claim to be multinational' (see also Stacey 1993, Burgess et al 1995). In the same vein, Littlejohn (2003, p. 10) stated that "while similar factors across the world may mould the nature of the hotel sector (...), it is important to recognise that the way these express themselves in any particular area or location will often be particular'. As will be discussed below, this point is especially important for understanding territorial embeddedness of hotel groups.

Thirdly, because of the number of countries covered by each hotel group and the number of hotels comprised by each group outside its home market, the hotel industry is one of the most global service sectors (Contractor and Kundu 2000). The high level of internationalisation of the hotel industry can best be observed on the basis of the ten largest hotel groups (Table 2). The number of countries targeted by them ranges from 35 (Choice Hotels) to 100 (InterContinental and Starwood). Moreover, many hotel groups have now more hotels abroad than in their home markets. This applies particularly to European groups which, in contrast to their American counterparts, derive from smaller markets (compare e.g. Accor to Starwood).

Fourthly, one of the most typical features of the contemporary hotel sector is the existence of multiple well-recognised brands such as Hilton and Marriott, which capture firm-specific advantages, inform about the level of service (Mallampally and Zimny 2000) and reduce 'consumer risks associated with the purchase of intangible hotel services' (Connell 1992, p. 26). Indeed, owing to the fact that hotels have always been recognised by name, they have always held one of the attributes ascribed to branded products (Buttle 1986). 
The fifth attribute of the hotel industry is of critical importance to this paper. Characterised by high fixed costs of investment and high investment risk (i.e. hotels are very costly to build and cannot generate any revenue until they are opened), the hotel industry is largely dependent on the availability of capital which nowadays is usually sought outside the hotel industry (Contractor and Kundu 2000, Go and Pine 1995, Littlejohn 2003). This growing dependence on external sources of funding has given rise to the popularisation of various non-equity contractual arrangements such as franchise and management agreements (Contractor and Kundu 2000, Littlejohn 2003) - something that is discussed in more detail in the following section.

Due to the fact that it helps to explain several of the attributes discussed above, the final point - the relatively long history of international development of hotel groups - deserves particular attention. In contrast to the majority of service industries which started to internationalise in the last few decades, the development of hotel groups can be traced back to the end of the $19^{\text {th }}$ century (Contractor and Kundu 2000). Although it was initially very slow, the development of hotel groups accelerated after WWII when hotel groups appeared to be the most efficient framework through which the increasing mass tourist demand could be fulfilled (Kowalczyk 2001, 2003, Mitka-Karandziej 1993). The concentration tendencies in the hotel sector (i.e. horizontal integration of the hotel industry) after WWII could be described as a shift from a pre-Fordist to a Fordist system of production (Ioannides and Debbage 1998b). However, in contrast to the USA where the development of hotel groups was the fastest (notable examples including Holiday Inn and Marriott) the concentration in Europe was initially slower and limited mainly to looser forms of affiliation (Kowalczyk 2001, 2002, Mitka-Karandziej 1993). Horizontal integration of the hotel sector after WWII was also accompanied by the growth of hotel groups associated with airlines (i.e. vertical integration of the tourism sector). While the aim of horizontal integration was to bring economies of scale, the aim of vertical integration was to control more stages in the supply chain (Littlejohn 2003, Lafferty and van Fossen 2001). Gradually, vertical integration also embraced the gambling industry, restaurants and tour-operators (Lafferty and van Fossen 2001, Włodarczyk 2003). However, due to the contrasting forms of organisation in each of these sectors, vertical integration eventually failed, thus pushing tourist companies to focus on their core businesses only (see Ioannides and Debbage 1998b and Lafferty and van Fossen 2001 for a more detailed discussion). 
The Fordist tendencies in the international hotel industry continued in the same manner until the 1980s, when processes of globalisation such as the fragmentation of demand and the increasing economic and political integration once again redefined the shape of the international hotel sector (Athiyaman and Go 2003). Indeed, in contrast to the 1960s and 1970s when the global market was perceived as homogeneous, in the 1990s the hotel sector found itself subject to various post-Fordist tendencies such as diversification of products, a growing sensitivity to cultural differences, the emergence of strategic alliances and the subsequent popularisation of various non-equity business models (Crawford-Welch 1992, Go and Pine 1995, Go and Moutinho 2000, Littlejohn 2003, Nickson 1998). Given that the rise of different business models has led to the emergence of various kinds of hotel groups' global production networks, attention to them is key to understanding the globalisation of the hotel sector. All main business models are analysed in detail in the following section.

\section{Business models of international hotel groups}

The most common categorisation of modes of expansion in services has been provided by the General Agreement on Trade in Services (GATS) which distinguished four main modes of expansion: cross-border supply, consumption supply, commercial presence and presence of persons (Rubalcaba-Bermejo and Cuadrado-Roura 2002a, 2002b, Schulz 2005). However, due to the fact that this taxonomy does not give enough consideration to various contractual arrangements, it is of limited use for the hotel industry. Therefore, it is more fruitful here to follow Vandermerwe and Chadwick (1989) who took a simpler approach and distinguished between trade, FDI (foreign direct investment) and contractual arrangements.

Given that tourism exports account for $6 \%$ of total export of goods and services and $30 \%$ of commercial services worldwide (UNWTO 2010), it could be erroneously inferred that trade is the most important mode of internationalisation of hotel services. Meanwhile, due to the fact that export of hotel services does not imply shipping products across national borders but rather these services being purchased by foreign visitors in the exporting nation (Smith 1998), it is of little importance to the international expansion of hotel groups. The same cannot be said of FDI and contractual arrangements, both of which assume a physical presence in the host market. The importance of FDI is clearly visible at the corporate level where mergers and acquisitions (M\&As) are frequent. Indeed, between 1987 and 2002 M\&As in the hotel sector accounted for $34 \%$ of all transactions in tourism (Endo 2006, UNCTAD 2004). In contrast, owing to the growing separation of ownership and control, the role of FDI at the property 
level is limited. While in the 1960s and 1970s hotel groups often owned the hotels which they operated, nowadays carrying an international brand in a host country does not necessarily mean that the hotel is owned by a given group (Endo 2006). In reality, the invested capital may originate either from local sources or from other foreign firms that invest in hotels but are not hotel groups. This especially applies to real estate investment trusts (REITs) that entered the hotel market in the 1990s (Kowalczyk 2003). All business models of hotel groups are briefly discussed below.

\section{Operator owning}

Given that hotel groups have mostly become management and franchise firms that offer their services to asset holders, operator owning is now of decreasing popularity (see Table 3 ). As a separate function from managing and franchising, hotel ownership is usually down to real estate firms which specialise in developing and owning the assets, or independent developers which employ a third party to manage the business on their behalf (Go and Pine 1995, Littlejohn 2003). Nonetheless, some hotel groups still own some hotel equity - either because they traditionally prefer to do so (especially in their home markets, e.g. Meliã Hotels International in Spain) or because they still have not entirely divested themselves of hotel real estate in their switch from equity to non-equity business models (e.g. Hilton Worldwide). Due to the fact that owning entails direct investment of capital (León-Darder et al 2011), it is a high-commitment model and, from the perspective of hotel groups, it is a very slow mode of international development (Cunill 2006). As León-Darder et al (2011) point out, the investment may be either greenfield (newly built hotels) or brownfield (take-overs of existing outlets). Ownership can be either partial (a joint venture) or whole (León-Darder et al 2011). In each case the hotel group is an operator that retains control over daily operations and codified assets such as the brand (León-Darder et al 2011). Operator owning is the only business model that can be classed as hotel industry FDI (Endo 2006).

\section{Managing}

Alongside franchising, managing is the most popular business format in the hotel industry. A management contract is a legal agreement where the asset holder employs an operator to professionally manage the hotel (Athiyaman and Go 2003, Cunill 2006). While the owner retains full control over the physical assets, the control over daily operations is passed to the operator that implements systems, standards and procedures, employs staff and normally also provides a brand (León-Darder et al 2011). The operator is paid a fee and is expected to take 
full responsibility for the hotel's performance (Go and Pine 1995, Littlejohn 2003). For this reason, hotel owners tend to select operators very carefully (Cunill 2006, Go and Pine 1995). Despite the fact that management contracts are a medium- and not low-commitment mode of entry, the majority of well-known hotel groups strongly prefer management contracts to other arrangements because of the high level of control involved. For many upscale hotel groups such as Four Seasons, Hyatt and Protea managing is either the only or the most dominant mode of expansion. Management agreements are usually long, lasting from 20 to 50 years (Go and Pine 1995).

\section{Leasing}

Perhaps because of the similarities between lease agreements and management contracts in terms of the hotel group's operating responsibilities, leasing as a business model in the hotel industry has received so far very little attention in literature. Indeed, the literature committed to business models of hotel groups either does not recognise leasing (see Chen and Dimou 2005, Go and Pine 2005, León-Darder et al 2011, Quer et al 2007 and Rodriguez 2002) or considers it along with management. Some noteworthy exceptions include Cunill (2006), Koh and Jang (2009) and Whittaker (2008). In practice, leasing and managing differ widely in terms of the commitment and risk involved. Under a lease agreement the hotel operator (the lessee) leases the hotel from the hotel owner (the lessor) and is entitled to the benefits of, and carries the risks associated with, operating the hotel (www.rezidor.com). In contrast to management contracts where the revenue goes to the owner and the operator is paid a fee from revenue, in lease agreements the revenue goes to the operating company which pays a rent to the asset holder (Cunill 2006, www.rezidor.com). Thus, compared to managing, the supplier-consumer service relation between the operator and the owner is reversed. Due to the fact that lessees have to commit financially, leasing is a high-commitment model. Therefore, hotel groups which have the power to negotiate management contracts try to avoid leases (Elgonemy et al 2002, Whittaker 2008). Despite that, as a relatively quick mode of expansion, for some hotel groups such as Accor, The Rezidor Hotel Group, Barceló Hotels \& Resorts and $\mathrm{NH}$ Hoteles, leasing is a very important, or sometimes even preferred, format.

\section{Franchising}

Franchising is now one of the most common modes of expansion for hotel groups (Athiyaman and Go 2003). It can be defined as 'a business relationship whereby a franchisor permits a franchisee to use their brand name, product, or system of business in a specified and ongoing 
manner in return for a fee' (Felstead 1993, p. 58, see also Cunill 2006, Pizam 2005). In a franchise agreement the hotel owner/operator (the franchisee) 'buys in' a specific style of operation from the hotel group (the franchisor) who does not get involved in operating the hotel directly (Littlejohn 2003). The parent company provides the hotel owner with a brand and service concept and also offers various support activities such as marketing and staff training (Go and Pine 1995, Littlejohn 2003). While the hotel operator controls daily operations and the physical assets, the franchisor retains full control over the codified assets (León-Darder et al 2011). Franchising is thus a low-commitment business format that entails low risk and is an easy way of broadening the network (Abell 1990, Connell 1997, Cunill 2006, Eroglu 1992, León-Darder et al 2011). Therefore, in addition to groups traditionally relying on franchising (e.g. Choice Hotels), many hotel groups such as InterContinental have decided over years to entirely (or almost entirely) commit themselves to franchising instead of managing. In terms of duration, franchise contracts are shorter than management agreements.

\section{Hotel consortia}

A hotel consortium is an entirely separate type of hotel company that does not own, franchise or manage hotels. Instead, hotel consortia are alliances of independently-operated hotels that seek affiliation in a centralised organisation to take advantage of economies of scale, share corporate costs, conduct joint marketing activities and gain greater visibility in the market without giving up full control over their operations (Byrne 1993, Go and Pine 1995, Housden 1984, Littlejohn 2003, Pizam 2005, Roper 1995, Slattery et al 1985). Apart from marketing, services offered by consortia include managing distribution channels and in some cases also staff training (Byrne 1993). However, the range of services provided by each consortium differs. For instance, Best Western gives their hotels a brand and therefore functions in a similar manner to franchise companies. Usually, however, the activities of hotel consortia are limited to sales and marketing conducted in the background (e.g. TOP International Hotels). Finally, some hotel consortia (e.g. Utell) function only as global reservation systems (Byrne 1993, Slattery et al 1985). Owing to the fact that hotel consortia do not have a corporate identity in the usual sense (Roper 1995), they are not included in world rankings of hotel groups (Best Western being a noteworthy exception). Instead, they are ranked separately. Table 4 illustrates the ten largest hotel consortia in the world. Table 5 summarises all the discussed business models' main features. 


\section{Theorising the internationalisation/globalisation of the hotel industry}

Parallel to the increasing importance of services in the global economy, many attempts have been undertaken to theorise the internationalisation/globalisation of the service sector. The most popular theories include different versions of stages approach (Edvardsson et al 1993, O’Farrell et al 1998, Roberts 1999) and, most importantly, Dunning and Norman's (1983, 1987) eclectic paradigm, all developed within management and business studies. Unlike in economic geography, the international hotel industry has long been of interest to management and business studies scholars (see Slattery et al 2008 for a literature review) who, in order to explain its worldwide development, have almost unanimously tended to adopt the eclectic paradigm (Johnson and Vanetti 2005, Littlejohn et al 2007, Go and Pine 1995).

The eclectic paradigm argues that firms decide to internationalise if they have a competitive advantage over host firms. Three different kinds of advantages are distinguished: ownership, location and internalisation. While ownership (firm-specific) advantages relate to the firm's unique assets such as know-how, location advantages relate to the firm's access to resources in the host economy such as infrastructure and human resources, and to the attractiveness of the host market. Internalisation advantages, in turn, comprise the firm's ability to choose an appropriate mode of entry to protect its knowledge (Bryson et al 2004, Faulconbridge et al 2008, Johnson and Vanetti 2005, O'Farrell et al 1998, UNCTAD 2004). Although the eclectic paradigm is very helpful in accounting for the growth and distribution of hotel groups (see Burgess et al 1995, Go and Pine 1995, Johnson and Vanetti 2005), it falls short of explaining the globalisation of the hotel sector in at least three important respects.

First, as a firm-centric approach, the paradigm does not recognise that the international expansion of the hotel sector also depends on many other actors, be they local authorities, NGOs or firms representing other service industries. It has been only recently that the availability of partners (Brown et al 2003, Dev et al 2007) and access to funding (Altinay and Altinay 2003) have been recognised as important factors determining the worldwide development of hotel groups. In contrast, the role of consulting firms, which are employed by hotel owners to conduct market research and to select an appropriate operator or a franchisor for the property (thus linking hotel developers to the global production networks of international hotel groups and acting as gatekeepers for both parties) is still one of the most under-researched areas. Therefore, given the increasing separation of ownership and control and the growing involvement of actors from outside the hotel sector, it is necessary to 
acknowledge that hotel groups do not function in a vacuum and that their production networks are complex, multi-actor and multi-scalar systems of power relations.

The remaining two gaps reflect the fact that the eclectic paradigm is preoccupied with various reasons why firms expand and what modes of entry they choose and thus neglects their postentry behaviour (O'Farrell et al 1998) and the implications which the entry mode choice has in general. Meanwhile, as Faulconbridge et al (2008) observed with regard to headhunting firms, the strategies of internationalisation in the service sector are messier than the paradigm implies and, therefore, it is necessary to pay more attention to how different expansion strategies interact with various features of host markets (Faulconbridge et al 2008) - i.e. to what extent service firms are embedded in host markets on the one hand (the second gap) and what impact on host economies they have on the other (the third gap).

Therefore, given the so-called 'localised focus' of the hotel industry, combined with its global extent in terms of the high number of countries covered by many groups, it is necessary to focus on the various characteristics of the places into which hotel groups expand. While the economic, socio-political and institutional diversity in the world has long been recognised as a critical factor determining their expansion (Go and Pine 1995, Littlejohn 2003, Olsen and Merna 1993), the territorial embeddedness of hotel groups in host economies is still underresearched. Meanwhile, it might be expected that the general understanding of the hotel sector could benefit from examining the ways in which hotel groups are 'placed' within different environments at different scales and in which different places are inserted into hotel GPNs (Dicken 2003). Likewise, one of the biggest research gaps is the influence of expanding hotel groups on the host economy. Although the role of the hotel industry in generating employment, regenerating urban cores and contributing to technology and knowledge transfer has been acknowledged (Britton 1991, Chang et al 1996, Go and Pine 1995, Milne and Pohlmann 1998, Pine 1992, Watson 1991), the various categories of impact have neither been investigated in detail, nor integrated into studies of different expansion strategies of hotel groups. It is therefore essential to explore which actors from within hotel GPNs generate and enhance the value, for the benefit of whom this value is captured and to what extent these processes depend on different expansion strategies.

Due to the fact that the identified gaps are geographical in nature, a geographical approach could potentially provide a clearer understanding of the globalisation of the hotel sector than 
the eclectic paradigm. Therefore, following Coe (2004) who put forward a similar argument with regard to retailing, this paper argues the case for the global production networks (GPN) approach as an effective theoretical platform from which the identified gaps can be tackled. Developed in the early 2000s by Henderson et al (2002, see also Coe et al 2008a, Coe 2012, Hess and Yeung 2006), the GPN approach is an interpretative framework for analysing the global economy that looks at economic development and its spatial asymmetries from the perspective of economic geography. Its applicability to research on globalisation derives from its holistic nature and the fact that, rather than privileging any spatial scale or a group of actors, it brings different foci of analysis in an integrated form (Hess and Yeung 2006). This largely distinguishes GPN from its antecedents - especially the global commodity/value chains (GCC/GVC) concept (Gereffi et al 1994, 2005, Sturgeon 2001). The key advantages of the GPN approach over GCC/GVC are broadly discussed by Coe et al (2008a), Henderson et al (2002) and Hess and Yeung (2006). A detailed critique of the GCC concept on which the GPN approach also largely rests is provided by Smith et al (2002). Bair (2005), in turn, offers a detailed comparison of GPN, GCC and GVC.

More specifically, the potential of the GPN approach to tackle the under-researched aspects of the globalisation of the hotel industry lies in its three fundamental conceptual categories power, embeddedness and value, each of which directly relates to one of the three identified research gaps. Thus, through focusing on different kinds of power (corporate, institutional, collective) (Henderson et al 2002) and accounting for different power relations between actors within hotel GPNs, it is possible to explore the complex multi-actor nature of the international hotel industry. The category of embeddedness, in turn, which may refer to the firm's network (network embeddedness), host economies (territorial embeddedness) and the firm's home country (societal embeddedness) (Henderson et al 2002, Hess 2004), is a good platform from which the various interactions between expanding hotel groups and the variety of markets which they target can be investigated in more depth. Finally, focusing on the category of value, the GPN framework considers the multiple ways in which value can be created, enhanced and captured for the benefit of various locations and actors (Henderson et al 2002) and in which strategic couplings between hotel GPNs and the various places which they interconnect can evolve (Coe et al 2004, Yeung 2009).

Crucially, it is necessary to acknowledge that applying a chain/network approach to tourism in order to tackle similar research gaps is not an entirely new idea in economic geography. 
Clancy (1998) and Mosedale (2006, 2008), who employed the GCC framework to explain the tourism production system on the basis of package tourism from Europe to Jordan and St. Lucia, respectively, should be credited here as pioneers. The work of Judd (2006), who argued for the GCC approach to tourism and attempted to define the inputs of the tourism product, and Erkuş-Öztürk and Terhorst (2010), who used the GVC framework to analyse the territorial embeddedness of tourism value chains from Holland to Turkey, also should be recognised. The work of d'Hauteserre (2006) who provided a critique of the GCC framework and argued instead for actor-network theory (ANT) as a more promising framework for analysing the complexity of tourism production also serves as a good example. And finally, it is necessary to acknowledge the work of Christian (2012) and Christian and Mwaura (2013) who adopted the GPN perspective to analyse the development of the tourism sector in Uganda and Kenya.

The advantage of the GPN approach over GCC/GVC originates from the fact that not only does it capitalise on its strengths, but also - through the incorporation of selected assumptions of ANT (see Whatmore and Thorne 1997) and the varieties of capitalism (VoC) set of approaches (see Hall and Soskice 2001, Hollingsworth and Boyer 1997, Whitley 1999) - it effectively overcomes its shortcomings. While ANT is of help in explaining economic globalisation as a set of processes that are uneven, unstable and dependent on relations and negotiations between agents (much in line with d'Hauteserre's (2006) critique of GCC), VoC accounts for the multiplicity of regulatory systems in which GPNs are embedded. That the GPN approach can be considered a more effective theory than its antecedents in accounting for the multi-actor nature of the hotel sector and the territorial embeddedness of expanding hotel groups has also been demonstrated by a number of studies on different service and nonservice sectors. For example, with regard to the multi-actor nature of different sectors, Coe et al (2008b) analysed the interactions between regulators, transnational agencies, local agencies and trade bodies in the temporary staffing industry in Poland and the Czech Republic, whereas Johns (2006) enquired into the power relations between different actors in the video games industry. In relation to the territorial embeddedness of expanding companies, Coe and Lee (2006) and Coe et al (2011) showed how in retailing and temporary staffing (respectively) a high level of territorial embeddedness may be key to success in a foreign market (see also Coe 2012). Because of their joint adoption of GPN and VoC the research on the territorial embeddedness of retail corporations by Wrigley et al (2005) also should be mentioned here. Finally, as the research by Coe and Wrigley (2007) on retailing 
demonstrated, the GPN approach is also well-suited to enquire into host economy impacts of expanding corporations. Thus, with regard to Dicken's (1998) distinction between internationalisation, defined as the extension of corporate activities across national borders, and globalisation, understood as the functional integration of cross-border activities, the GPN approach has the potential to account not only for the internationalisation of the hotel sector but also, unlike the eclectic paradigm, for its actual globalisation.

However, to account for the globalisation of the hotel industry from the GPN perspective, it is also essential to pay attention to different types of hotel GPNs. This is where an enhanced understanding of business models of hotel groups can prove helpful. First, with regard to the multi-actor nature of the hotel sector, it is critical to recognise that the choice of business model not only defines the division of responsibilities between the hotel owner and the hotel group but it also determines the structure of power relations between the other actors involved. In other words, it depends on the business model which party represents the hotel in dealing with local authorities, suppliers and trade unions. Whereas it is normally down to equity holders to find a source of funding, apply for a building permit and seek help from consulting firms, the majority of operational responsibilities are passed to the operator. If, however, the owner operates the hotel on its own and only employs a hotel group to franchise the property, the responsibilities of the franchisor are limited to sales and marketing. Because franchisors do not get involved in operating issues, their relations with local authorities are usually weakly developed. The same applies to hotel consortia. Simultaneously, it is easy to infer that the entry mode choice is often influenced by other actors. As discussed earlier, it especially applies to consultant firms, however, it may also pertain to political authorities responsible for determining the legal conditions in which the investment takes place and which may therefore favour particular business models more than others.

Secondly, the selection of entry mode also determines the level of territorial embeddedness of the hotel group, the level of its financial commitment and the nature of interactions between the hotel group and the host territory. Thus, hotel groups which own hotels interact with local contexts more intensively than hotel operators which normally do not face bureaucratic hurdles associated with developing the property. However, unlike franchisors and consortia, hotel operators are still largely dependent on various local regulations concerning, for instance, employment. Thirdly, the same applies to the influence that hotel groups have on host markets. In contrast to franchisors and consortia which do not invest themselves and do 
not get involved in operating issues, hotel groups which own hotels (and also hotel operators) have greater potential to foster regional development in the host economy. This may include creating jobs, enhancing demand for products and services and upgrading local infrastructure. The example of a stylised global production network of an international hotel group presented in Figure 1 can serve as a visual summary of the above discussion and a foundation on which detailed empirical research can be based. As the figure implies, actors within hotel GPNs can be divided into two groups - those that play a role at the property development stage and those that influence the day-to-day operations of the hotel. The arrows in the figure represent different flows (such as those of goods and services between the hotel and suppliers), different kinds of impact (such as that of banks on the asset holder) or different kinds of cooperation (such as that between the hotel and the local authorities). Some arrows may represent more than one kind of relationship.

Finally, due to the fact that the research gaps identified above with regard to the hotel industry overlap with the most under-researched aspects of the globalisation of services in general (see Faulconbridge et al 2008), it is worth distilling why researching the hotel sector from the GPN perspective can have important implications on how the globalisation of services is theorised. First, the example of the hotel industry shows that it is necessary to break away from firmcentricity and pay more attention to complex power relations between various groups of actors constituting a given industry. Secondly, it demonstrates that rather than analysing any service sector 'in isolation', it is essential to give consideration to the interdependencies between different service industries and account for the broadly-defined context in which the industry operates. Concurrently, because of its inherent characteristics, the hotel industry can also prove to be a good sectoral case through which the theoretical understanding of the globalisation of services can move beyond modes of entry and reasons for expansion and embrace the interactions between expanding service firms and various features of host territories. Therefore, following Beaverstock et al (1999), Faulconbridge et al (2008) and Warf (2001) who showed that different strategies of internationalisation lead to different types of integration, it is easy to expect that enhanced attention to business models of hotel groups and their post-entry effects can be a promising avenue to follow if the general understanding of the globalisation of services is to be advanced. 


\section{Conclusions}

The paper has argued that the worldwide development of the hotel industry has progressed to the level where it can no longer be neglected by economic geographers if the global tourism production system and, more generally, the globalisation of services are to be sufficiently understood, interpreted and theorised. By means of identifying the limitations of Dunning and Norman's $(1983,1987)$ eclectic paradigm the paper has highlighted three distinct research gaps in the existing research on the hotel sector - the multi-actor nature of the hotel industry, the territorial embeddedness of hotel groups and the impact of expanding hotel groups on economic growth in host markets. As has been demonstrated, research on the hotel industry largely suffers from an insufficient attention to how activities of hotel groups are functionally integrated across various spatial scales and different economic and political environments into which they expand. Due to the fact that these gaps are geographical in nature, the paper has argued the case for the global production networks (GPN) approach as an effective platform from which they can be addressed. Because of its focus on the conceptual categories of power, value and embeddedness, the GPN approach is of particular utility in analysing the development and operations of the hotel sector. Simultaneously, because of its inherent attributes - especially the wide variety of business models of hotel groups - the hotel industry is a good sectoral case through which the theoretical understanding of the globalisation of services can escape from firm-centricity, move beyond reasons for expansion and fully embrace post-entry behaviour of expanding service corporations. Finally, it is hoped that by proving the value of economic-geographical research on the hotel sector, the paper has shown that, if economic globalisation is to be accounted for, tourism production should no longer be neglected by economic geographers.

\section{References}

\section{Abell, M. (1990) The International Franchise Option (London: BFA Waterflow)}

Agarwal, S., Ball, R., Shaw, G. Williams, A. (2000) The geography of tourism production: uneven disciplinary development, Tourism Geographies, 2(3), pp. 241-263

Altinay, L., Altinay, M. (2003) How will growth be financed by international hotel companies? International Journal of Contemporary Hospitality Management, 15, pp. 274-282

Athiyaman, A., Go, F. (2003) Strategic choices in the international hospitality industry, in: Brotherton, B. (ed.) The International Hospitality Industry: Structure Characteristics and Issues (Oxford: Butterworth-Heinemann), pp. 142-159 
Bair, J. (2005) Global capitalism and commodity chains: looking back, going forward, Competition \&Change, 9 , pp. 153-180

Beaverstock, J., Smith, R., Taylor, P. (1999) The long arm of the law: London's law firms in a globalising world economy, Environment and Planning A, 31, pp. 1857-1876

Britton, S. (1991) Tourism, capital and place: towards a critical geography of tourism, Environment and Planning D: Society and Space, 9, pp. 451-478

Brown, J., Dev, C., Zhou, Z. (2003) Broadening the foreign market entry mode decision: separating ownership and control, Journal of International Business Studies, 34, pp. 473-488

Bryson, J. (2001) Services and internationalisation: annual report on the progress of research into service activities in Europe in 1998, The Service Industries Journal, 21, pp. 227-240

Bryson, J., Daniels, P.,Warf, B. (2004) Service Worlds (London: Routledge)

Burgess, C., Hampton, A., Price, L., Roper, A. (1995) International hotel groups: what makes them successful?, International Journal of Contemporary Hospitality Management, 7, pp. 7480

Butler, R. (2004) Geographical research on tourism, recreation and leisure: origins, eras and directions, Tourism Geographies, 6, 2, pp. 143-162

Butler, R. (2012) Tourism geographies of geographies of tourism: Where the bloody hell are we?, in: Wilson, J. (ed.) The Routledge Handbook of Tourism Geographies, London: Routledge, pp. 26-34

Buttle, F. (1986) Hotel and Food Service Marketing (London: Cassell)

Byrne, A. (1993) International hotel consortia, in: Jones, P., Pizam, A. (eds.) The International Hospitality Industry: Organizational and Operational Issues, (New York: Pitman Publishing/John Wiley \& Sons, Inc.), pp. 126-132

Chang, T., Milne, S., Fallon, D., Pohlmann, C. (1996) Urban heritage tourism: the globallocal nexus, Annals of Tourism Research, 23, pp. 284-305

Chen, J., Dimou, I. (2005) Expansion strategy of international hotel firms, Journal of Business Research, 58, pp. 1730-1740

Christian, M. (2012) Economic and social up(down)grading in tourism global production network: findings from Kenya and Uganda, working paper 11, Capturing the Gains, retrieved from www.capturingthegains.org/publications/workingpapers in April 2013

Christian, M., Mwaura, F. (2013) Economic and social upgrading in tourism global production networks: findings from Uganda, working paper 19, Capturing the Gains, retrieved from www.capturingthegains.org/publications/workingpapers in April 2013 
Clancy, M. (1998) Commodity chains, services and development: theory and preliminary evidence from the tourism industry, Review of International Political Economy, 5, pp. 122148

Coe, N. (2004) The internationalisation/globalisation of retailing: towards an economicgeographical research agenda?, Environment and Planning A, 36, pp. 1571-1594

Coe, N. (2012) Geographies of production II: a global production network A-Z, Progress in Human Geography, 36, 3, pp. 389-402

Coe, N., Hess, M., Yeung, H., Dicken, P., Henderson, J. (2004) 'Globalizing' regional development: a global production networks perspective, Transactions of the Institute of British Geographers, New Series, 29, pp. 468-484

Coe, N., Dicken, P., Hess, M. (2008a) Global production networks: realizing the potential, Journal of Economic Geography, 8, pp. 271-295

Coe, N., Johns, J., Ward, K. (2008b) Flexibility in action: the temporary staffing industry in the Czech Republic and Poland, Environment and Planning A, 40, pp. 1391-1415

Coe, N., Johns, J., Ward, K. (2011) Variegated global expansion: internationalization strategies in the temporary staffing industry, Geoforum, 42, pp. 61-70

Coe, N., Lee, Y. (2006) The strategic localization of transnational retailers: the case of Samsung-Tesco in South Korea, Economic Geography, 82, pp. 66-88

Coe, N., Wrigley, M. (2007) Host economy impacts of transnational retail: the research agenda, Journal of Economic Geography, 7, pp. 341-371

Connell, J. (1992) Branding hotel portfolios, International Journal of Contemporary Hospitality Management, 4, pp. 26-32

Connell, J. (1997) International hotel franchise relationships - UK franchisee perspective, International Journal of Contemporary Hospitality Management, 9, pp. 215

Contractor, F., Kundu, S. (2000) Globalization of hotel services: an examination of ownership and alliance patterns in a maturing service sector, in: Aharoni, Y., Nachum, L. (eds.)

Globalization of Services (London: Routledge), pp. 296-319

Crawford-Welch, S. (1992) Competitive marketing strategies in the international hospitality industry, in: Teare, R., Olsen, M. (eds.) International Hospitality Management: Corporate Strategy in Practice (London: John Wiley \& Sons), pp. 95-109

Cunill, O. (2006) The Growth Strategies of Hotel Chains: Best Business Practices by Leading Companies (New York: The Haworth Hospitality Press)

d'Hauteserre, A. (2006) A response to 'Tracing the commodity chain of global tourism' by Dennis Judd, Tourism Geographies, 8(4), pp. 337-342 
Debbage, K., Daniels, P. (1998) The tourist industry and economic geography: missed opportunities, in: Ioannides, D., Debbage, K. (eds.) The Economic Geography of the Tourist Industry: A Supply-side Analysis (London \& New York: Routledge), pp. 17-30

Debbage, K., Ioannides, D. (2012) The economy of tourism spaces: A multiplicity of 'critical turns'?, in: Wilson, J. (ed.) The Routledge Handbook of Tourism Geographies (London: Routledge), pp. 149-156

Dev, C., Brown, J., Zhou, Z. (2007) Global brand expansion: how to select a market entry strategy, Cornell Hotel and Restaurant Administration Quarterly, 48, pp. 13-27

Dicken, P. (1998) Global Shift: Transforming the World Economy, $3^{\text {rd }}$ edition (London: Paul Chapman)

Dicken, P. (2003) 'Placing' firms: grounding the debate on the 'global' corporation, in: Peck, J., Yeung, H. (eds.) Remaking the Global Economy (London: Sage), pp. 27-44

Dunning, J., Norman, G. (1983) The theory of the multinational enterprise: an application of an international office location, Environment and Planning A, 15, pp. 675-692

Dunning, J., Norman, G. (1987) The location choice of offices of international companies, Environment and Planning A, 19, pp. 613-631

Edvardsson, B., Edvinsson, L., Nyström, H. (1993) Internationalisation in service companies, The Service Industries Journal, 13, pp. 80-97

Elgonemy, A., Craig, T., Gibson, D. (2002) Hotel sale-leaseback transactions, Jones Lang Lasalle, Hotel Topics, 11

Endo, K. (2006) Foreign direct investment in tourism - flows and volumes, Tourism Management, 27, pp. 600-614

Erkuş-Öztürk, H., Terhorst, P. (2010) Variety of modes of governance of a global value chain: the case of tourism from Holland to Turkey, Tourism Geographies, 12(2), pp. 217-245

Eroglu, S. (1992) The internationalisation process of franchise systems: a conceptual model, International Marketing Review, 9, pp. 19-30

Euromonitor (2010a) State of the Global Hotel Industry, Euromonitor International, retrieved from www.portal.euromonitor.com in May 2010

Euromonitor (2010b) Global Hotels: Lagging But Not Lost, Euromonitor International, retrieved from www.portal.euromonitor.com in December 2011

Faulconbridge, J., Hall, S., Beaverstock, J. (2008) New insights into the internationalization of producer services: organizational strategies and spatial economies for global headhunting firms, Environment and Planning A, 40, pp. 210-234

Felstead, A. (1993) The Corporate Paradox: Power and Control in the Business Franchise (London: Routledge) 
Gereffi, G., Humphrey, J., Sturgeon, T. (2005) The governance of global value chains, Review of International Political Economy, 12, pp. 78-104

Gereffi, G., Korzeniewicz, M., Korzeniewicz, R. (1994) Introduction: global commodity chains, in: Gereffi, G., Korzeniewicz, M. (eds.) Commodity Chains and Global Capitalism (Westport: Praeger), pp. 1-14

Gibson, C. (2008) Locating geographies of tourism, Progress in Human Geography, 32(3), pp. 407-422

Gibson, C. (2009) Geographies of tourism: critical research on capitalism and local livelihoods, Progress in Human Geography, 33(4), pp. 527-534

Go, F., Choi, T., Chan, C. (1996) Four Seasons-Regent: building a global presence in the luxury market, Cornell Hotel and Restaurant Administration Quarterly, 37, pp. 58-65

Go, F., Moutinho, L. (2000) International tourism management, in: Moutinho, L. (ed.) Strategic Management in Tourism (Oxford: CABI), pp. 315-336

Go, F., Pine, R. (1995) Globalization Strategy in the Hotel Industry (New York/London: Routledge)

Hall, C. (2005) Reconsidering the geography of tourism and contemporary mobility, Geographical Research, 43, pp. 125-139

Hall, C., Page, S. (2006) The Geography of Tourism \& Recreation: Environment, place and space, $3^{\text {rd }}$ Edition (Abingdon: Routledge)

Hall, C., Page S. (2009) Progress in Tourism Management: from the geography of tourism to geographies of tourism - a review, Tourism Management, 30, pp. 3-16

Hall, C., Page, S. (2012) From the geography of tourism to geographies of tourism, in: Wilson, J. (ed.) The Routledge Handbook of Tourism Geographies (London: Routledge), pp. 9-25

Hall, P., Soskice, D. (eds.) (2001) Varieties of Capitalisms: The Institutional Foundations of Comparative Advantage (Oxford: Oxford University Press)

Henderson, J., Dicken, P., Hess, M., Coe, N., Yeung, H. (2002) Global production networks and the analysis of economic development, Review of International Political Economy, 9, pp. 436-464

Hess, M. (2004) 'Spatial' relationships? Towards a reconceptualization of embeddedness, Progress in Human Geography, 28, pp. 163-186

Hess, M., Yeung, H. (2006) Guest editorial, Environment and Planning A, 38, pp. 1193-1204 
Hollingsworth, J., Boyer, R. (1997) Coordination of economic actors and social systems of production, in: Hollingsworth, J., Boyer, R. (eds.) Contemporary Capitalism: The Embeddedness of Institutions (Cambridge: Cambridge University Press)

Hotels’ 325 (2011) Hotels, retrieved from www.hotelsmag.com in December 2011

Housden, J. (1984) Franchising and Other Business Relationships in Hotel and Catering Services (London: Heinemann)

Ioannides, D. (1995) Strengthening the ties between tourism and economic geography: a theoretical agenda, Professional Geographer, 47, pp. 49-60

Ioannides, D. (2006) Commentary: The economic geography of the tourist industry: ten years of progress in research and an agenda for the future, Tourism Geographies, 8(1), pp. 76-86

Ioannides, D., Debbage, K. (1998a) Introduction: exploring the economic geography and tourism nexus, in: Ioannides, D., Debbage, K. (eds.) The Economic Geography of the Tourist Industry: A Supply-side Analysis (London \& New York: Routledge), pp. 1-14

Ioannides, D., Debbage, K. (1998b) Neo-Fordism and flexible specialization in the travel industry: dissecting the polyglot, in: Ioannides, D., Debbage, K. (eds.) The Economic Geography of the Tourist Industry: A Supply-side Analysis (London \& New York: Routledge), pp. 99-122

Johns, J. (2006) Video games production networks: value capture, power relations and embeddedness, Journal of Economic Geography, 6, pp. 151-180

Johnson, C., Vanetti, M. (2005) Locational strategies of international hotel chains, Annals of Tourism Research, 32, pp. 1077-1099

Judd, D. (2006) Commentary: Tracing the commodity chain of global tourism, Tourism Geographies, 8(4), pp. 323-336

Koh, J., Jang, S. (2009) Determinants of using operating lease in the hotel industry, International Journal of Hospitality Management, 28, pp. 638-640

Kowalczyk, A. (2001) Geografia Hotelarstwa (Łódź: Wydawnictwo Uniwersytetu Łódzkiego)

Kowalczyk, A. (2002) Współczesne tendencje na rynku największych systemów hotelowych na świecie, Turystyka i Hotelarstwo, 2, pp. 9-32

Kowalczyk, A. (2003) Zmiany w największych systemach hotelowych świata na przełomie XX i XXI w., Turystyka i Hotelarstwo, 3, pp. 79-88

Lafferty, G., van Fossen, A. (2001) Integrating the tourism industry: problems and strategies, Tourism Management, 22, pp. 11-19 
León-Darder, F., Villar-Garcia, C., Pla-Barber, J. (2011) Entry mode choice in the internationalization of the hotel industry: a holistic approach, The Service Industries Journal, 31, pp. 107-122

Lew, A. (2011) Tourism's Role in the Global Economy, Tourism Geographies, 13(1), pp. $148-151$

Littlejohn, D. (2003) Hotels, in: Brotherton, B. (ed.) The International Hospitality Industry: Structure Characteristics and Issues (Oxford: Butterworth-Heinemann), pp. 5-29

Littlejohn, D., Roper, A., Altinay, L. (2007) Territories still to find - the business of hotel internationalization, International Journal of Service Industry Management, 18, pp. 167-183

Lundberg, D., Krishnamoorthy, M., Starvey, M. (1995) Tourism Economics (New York: John Wiley \& Sons)

Mallampally, P., Zimny, Z. (2000) Foreign direct investment in services, in: Aharoni, Y., Nachum, L. (eds.) Globalization of Services (London: Routledge), pp. 25-51

Mather, S., Todd, G. (2002) The European Hotel Industry: An In-depth Analysis of Europe's Leading Global, National and Regional Companies (Beaconsfield: Travel Research International Ltd.)

Milne, S., Ateljevic, I. (2001) Tourism, economic development and the global-local nexus: theory embracing complexity, Tourism Geographies, 3(4), pp. 369-393

Milne, S., Pohlmann, C. (1998) Continuity and change in the hotel sector: some evidence from Montreal, in: Ioannides, D., Debbage, K. (eds.) The Economic Geography of the Tourist Industry: A Supply-side Analysis (London \& New York: Routledge), pp. 180-196

Mitka-Karandziej, U. (1993) Hotelarstwo, Zespół Prywatnych Szkół Zawodowych nr 1, Warszawa, Working Paper

Mosedale, J. (2006) Tourism commodity chains: market entry and its effects on St. Lucia, Current Issues in Tourism, 9, pp. 436-458

Mosedale, J. (2008) The internationalisation of tourism commodity chains, in: Coles, T., Hall, M. (eds.) International Business and Tourism: Global Issues, Contemporary Interactions (London: Routledge), pp. 149-166

Nickson, D. (1998) A review of hotel internationalisation with a particular focus on the key role played by American organisations, Progress in Tourism and Hospitality Research, 4, pp. 53-66

Niewiadomski, P. (2011) International Hotel Groups and Regional Development in Central and Eastern Europe, unpublished PhD thesis, The University of Manchester, UK

O'Farrell, P., Wood, P., Zheng, J. (1998) Regional influences on foreign market development by business service companies: elements of a strategic context explanation, Regional Studies, 32, pp. 31-48 
Olsen, M., Merna, K. (1993) The changing character of the multinational hospitality firm, in: Jones, P., Pizam, A. (eds.) The International Hospitality Industry: Organizational and Operational Issues (New York: Pitman Publishing/John Wiley \& Sons, Inc.), pp. 89-103

Page, S. (1995) Urban Tourism (London: Routledge)

Papatheodorou, A. (2003) Corporate strategies of British tour operators in the Mediterranean region: an economic geography approach, Tourism Geographies, 5(3), pp. 280-304

Pine, R. (1992) Technology transfer in the hotel industry, International Journal of Hospitality Management, 11, pp. 3-22

Pizam, A. (2005) (ed.) International Encyclopedia of Hospitality Management (Burlington: Elsevier)

Quer, D., Claver, E., Andreu, R. (2007) Foreign market entry mode in the hotel industry: the impact of country- and firm-specific factors, International Business Review, 16, pp. 362-376

Reiser, D. (2003) Globalisation: an old phenomenon that needs to be rediscovered for tourism?, Tourism and Hospitality Research, 4, pp. 306-320

Roberts, J. (1999) The internationalisation of business service firms: a stages approach, The Service Industries Journal, 19, pp. 68-88

Rodriguez, A. (2002) Determining factors in entry choice for international expansion: the case of the Spanish hotel industry, Tourism Management, 23, pp. 597-607

Rogerson, J. (2010) The boutique hotel industry in South Africa: definition, scope and organization, Urban Forum, 21, 4, pp. 425-439

Rogerson, J. (2011a) The changing all-suite hotel in South Africa: from "extended stay" to African "condo hotel", Tourism Review International, 15, pp. 107-121

Rogerson J. (2011b) The limited service hotel in South Africa: the growth of City Lodge, Urban Forum, 22, 4, pp. 343-361

Rogerson, J. (2013) Reconfiguring South Africa's hotel industry 1990-2010: Structure, segmentation, and spatial transformation, Applied Geography, 36, pp. 59-68

Rogerson J., Kotze, N. (2011) Market segmentation and the changing South African hotel industry 1990-2010, African Journal of Business Management, 5, 35, pp. 13523-13533

Roper, A. (1995) The emergence of hotel consortia as transorganizational forms, International Journal of Contemporary Hospitality Management, 7, pp. 4-9

Rubalcaba-Bermejo, L., Cuadrado-Roura, J. (2002a) Services in the age of globalisation: explanatory interrelations and dimensions, in: Cuadrado-Roura, J., Rubalcaba-Bermejo, L., Bryson, J. (eds.) Trading Services in the Global Economy (Cheltenham: Edward Elgar), pp. $27-57$ 
Rubalcaba-Bermejo, L., Cuadrado-Roura, J. (2002b) A comparative approach to the internationalisation of service industries, in: Cuadrado-Roura, J., Rubalcaba-Bermejo, L., Bryson, J. (eds.) Trading Services in the Global Economy (Cheltenham: Edward Elgar), pp. 78-108

Schulz, C. (2005) Foreign environments: the internationalisation of environmental producer services, The Services Industries Journal, 25, pp. 337-354

Slattery, P., Gamse, I., Roper, A. (2008) The development of international hotel chains in Europe, in: Olsen, M., Zhao, J., Pizam, A. (eds.) Handbook of Hospitality Strategic Management (Oxford: Butterworth-Heinemann), pp. 41-68

Slattery, P., Roper, A., Boer, A. (1985) Hotel consortia: their activities, structure and growth, Service Industries Journal, 5, pp. 192-199

Smith, A., Rainnie, A., Dunford, M., Hardy, J., Hudson, R., Sadler, D. (2002) Networks of value, commodities and regions: reworking divisions of labour in macro-regional economies, Progress in Human Geography, 26, pp. 41-63

Smith, S. (1998) Tourism as an industry: debates and concepts, in: Ioannides, D., Debbage, K. (eds.) The Economic Geography of the Tourist Industry: A Supply-side Analysis (London \& New York: Routledge), p. 31-52

Stacey, R. (1993) Strategic Management and Organisational Dynamics (Pitman Publishing, London)

Sturgeon, T. (2001) How do we define value chains and production networks?, IDS Bulletin, 32, pp. $9-18$

Tickell, A. (1999) The geographies of services: new wine in old bottles, Progress in Human Geography, 23, pp. 633-639

Tickell, A. (2001) Progress in the geography of services II: services, the state and the rearticulation of capitalism, Progress in Human Geography, 25, pp. 283-292

Tickell, A. (2002) Geography of services: progress in the geography of services III - time to move on?, Progress in Human Geography, 26, pp. 633-639

UNCTAD (2004) World Investment Report 2004: The Shift Towards Services (New York and Geneva: UNCTAD, United Nations)

UNWTO (2010) Tourism Highlights 2010, United Nations World Tourist Organisation, retrieved from www.unwto.org in April 2011

Vandermerwe, S., Chadwick, M. (1989) The internationalisation of services, The Services Industries Journal, 9, pp. 79-93

Warf, B. (2001) Global dimensions of US legal services, The Professional Geographer, 53, pp. 398-406 
Watson, S. (1991) Gilding the smokestacks: the new symbolic representations of deindustrialized regions, Environment and Planning D: Society and Space, 9, pp. 59-70

Whatmore, S., Thorne, L. (1997) Nourishing networks: alternative geographies of food, in: Goodman, D., Watts, M. (eds.) Globalizing Food: Agrarian Questions and Global Restructuring (London: Routledge)

Whitla, P., Walters, P., Davies, H. (2007) Global strategies in the international hotel industry, Hospitality Management, 26, pp. 777-792

Whitley, R. (1999) Divergent Capitalisms: The Social Structuring and Change of Business Systems (Oxford: Oxford University Press)

Whittaker, C. (2008) Hotel operator motives in UK sale and leaseback/management-back transactions, International Journal of Hospitality Management, 27, pp. 641-648

Włodarczyk, B. (2003) Systemy, łańcuchy hotelowe oraz inne struktury funkcjonalnoorganizacyjne w hotelarstwie - próba definicji, Turystyka i Hotelarstwo, 3, pp. 57-78

Wrigley, N., Coe, N., Currah, A. (2005) Globalizing retail: conceptualizing the distributionbased transnational corporation (TNC), Progress in Human Geography, 29, pp. 437-457

www.choicehotels.com - The official website of Choice Hotels International, accessed in April 2012

www.rezidor.com - The official website of The Rezidor Hotel Group, accessed in April 2011

Yeung, H., (2009) Regional development and the competitive dynamics of global production networks: an East Asian perspective, Regional Studies, 43, pp. 325-351 
Table 1. The largest hotel groups in the world by the number of rooms in 2010. Source: Hotels' 325 (2011)

\begin{tabular}{|c|c|c|c|c|}
\hline NO. & HOTEL GROUP & HQ & ROOMS & HOTELS \\
\hline 1. & InterContinental Hotels Group Plc & Denham, UK & 647161 & 4437 \\
\hline 2. & Marriott International Inc. & Bethesda, Maryland, USA & 618104 & 3545 \\
\hline 3. & Wyndham Worldwide & Parsippany, New Jersey, USA & 612735 & 7207 \\
\hline 4. & Hilton Worldwide & McLean, Virginia, USA & 604781 & 3671 \\
\hline 5. & Accor SA & Evry, France & 507306 & 4229 \\
\hline 6. & Choice Hotels International Inc. & Silver Spring, Maryland, USA & 495145 & 6142 \\
\hline 7. & $\begin{array}{l}\text { Starwood Hotels \& Resorts } \\
\text { Worldwide Inc. }\end{array}$ & White Plains, New York, USA & 308736 & 1041 \\
\hline 8. & Best Western International & Phoenix, Arizona, USA & 308692 & 4038 \\
\hline 9. & Carlson Hotels Worldwide & Minneapolis, Minnesota, USA & 162143 & 1064 \\
\hline 10. & Hyatt Hotels Corporation & Chicago, Illinois, USA & 127507 & 453 \\
\hline 11. & Westmont Hospitality Group & Houston, Texas, USA & 116913 & 813 \\
\hline 12. & $\begin{array}{l}\text { Shanghai Jin Jiang International Hotel } \\
\text { Group Co. Ltd. }\end{array}$ & Shanghai, China & 107019 & 707 \\
\hline 13. & Home Inns \& Hotel Management & Shanghai, China & 93898 & 818 \\
\hline 14. & The Rezidor Hotel Group & Brussels, Belgium & 87868 & 411 \\
\hline 15. & Meliá Hotels International & Palma de Mallorca, Spain & 87000 & 350 \\
\hline 16. & LQ Management LLC & Irving, Texas, USA & 83635 & 820 \\
\hline 17. & TUI Hotels \& Resorts & Hanover, Germany & 79511 & 261 \\
\hline 18. & Louvre Hotels Group & Paris, France & 78230 & 1023 \\
\hline 19. & Extended Hotel Stays & $\begin{array}{l}\text { Spartanburg, South Carolina, } \\
\text { USA }\end{array}$ & 77200 & 683 \\
\hline 20. & Iberostar Hotels \& Resorts & Palma de Mallorca, Spain & 67400 & 101 \\
\hline 21. & Vantage Hospitality Group Inc. & Coral Springs, Florida, USA & 60081 & 973 \\
\hline 22. & NH Hoteles SA & Madrid, Spain & 58687 & 397 \\
\hline 23. & 7 Days Group Holdings Ltd. & Guangzhou, China & 56410 & 568 \\
\hline 24. & Interstate Hotels \& Resorts & Arlington, Virginia, USA & 50666 & 242 \\
\hline 25. & China Lodging Group Ltd. & Shanghai, China & 50438 & 438 \\
\hline 26. & Barceló Hotels \& Resorts & Palma de Mallorca, Spain & 46922 & 182 \\
\hline 27. & MGM Resorts International & Las Vegas, Nevada, USA & 46533 & 17 \\
\hline 28. & Whitbread PLC & Leagrave, UK & 44062 & 593 \\
\hline 29. & Caesars Entertainment Inc. & Las Vegas, Nevada, USA & 42931 & 33 \\
\hline 30. & Riu Hotels \& Resorts & Playa de Palma, Spain & 42000 & 107 \\
\hline
\end{tabular}


Table 2. The degree of internationalisation of the ten largest hotel groups in the world in 2010 . Source: ${ }^{\mathrm{a}}$ Hotels' 325 (2011) (apart from * www.choicehotels.com), ${ }^{\mathrm{b}}$ Own elaboration on the basis of the hotel groups' official websites.

\begin{tabular}{|c|c|c|c|c|c|c|}
\hline \multirow[t]{2}{*}{ NO. } & \multirow[t]{2}{*}{ HOTEL GROUP $^{\mathrm{a}}$} & \multirow[t]{2}{*}{$\begin{array}{c}\text { HOME } \\
\text { COUNTRY }^{\mathrm{a}}\end{array}$} & \multirow[t]{2}{*}{$\begin{array}{l}\text { COUNTRIES } \\
\qquad(2010)^{\mathrm{a}}\end{array}$} & \multirow{2}{*}{$\begin{array}{c}\text { HOTELS } \\
\text { (TOTAL) } \\
(\mathbf{2 0 1 1})^{\mathrm{b}}\end{array}$} & \multicolumn{2}{|c|}{$\begin{array}{c}\text { HOTELS OUTSIDE THE } \\
\text { HOME COUNTRY } \\
(2011)^{b}\end{array}$} \\
\hline & & & & & (quantity) & $(\%)$ \\
\hline 1. & $\begin{array}{l}\text { InterContinental Hotels } \\
\text { Group Plc }\end{array}$ & UK & 100 & 4520 & 4245 & 93.9 \\
\hline 2. & Marriott International Inc. & USA & 70 & 3581 & 553 & 15.5 \\
\hline 3. & Wyndham Worldwide & USA & 67 & 7210 & 1301 & 18.0 \\
\hline 4. & Hilton Worldwide & USA & 82 & 3789 & 509 & 13.4 \\
\hline 5. & Accor & France & 90 & 4274 & 2846 & 66.6 \\
\hline 6. & $\begin{array}{l}\text { Choice Hotels International } \\
\text { Inc. }\end{array}$ & USA & $35^{*}$ & 6138 & 1178 & 19.2 \\
\hline 7. & $\begin{array}{l}\text { Starwood Hotels \& Resorts } \\
\text { Worldwide Inc. }\end{array}$ & USA & 100 & 1041 & 554 & 53.2 \\
\hline 8. & Best Western International & USA & 90 & 4032 & 2018 & 50.1 \\
\hline 9. & Carlson Hotels Worldwide & USA & 77 & 1070 & 495 & 46.3 \\
\hline 10. & Hyatt Hotels Corporation & USA & 45 & 478 & 119 & 24.9 \\
\hline
\end{tabular}


Table 3. Selected international hotel groups' preferred business models in 2010 (in \% of portfolio). Source: Own elaboration on the basis of the hotel groups' official websites.

\begin{tabular}{ccccc}
\hline HOTEL GROUP & Owning & \multicolumn{2}{c}{ BUSINESS MODELS } \\
& Leasing & Management & Franchising \\
\hline Starwood & 6 & 0 & 45 & 49 \\
Accor & 17 & 38 & 22 & 23 \\
InterContinental & 1 & 0 & 15 & 84 \\
Carlson Rezidor & 0 & 26 & 53 & 21 \\
\hline
\end{tabular}


Table 4. The largest hotel consortia in the world by the number of rooms in 2010. Source: Hotels' 325 (2011)

\begin{tabular}{lllcc}
\hline NO. & \multicolumn{1}{c}{ HOTEL CONSORTIUM } & \multicolumn{1}{c}{ HQ } & ROOMS & HOTELS \\
\hline $\mathbf{1 .}$ & Utell Hotels \& Resorts & Brentford, UK & 771200 & 6300 \\
$\mathbf{2 .}$ & Hotusa Hotels & Barcelon, Spain & 220000 & 2529 \\
$\mathbf{3 .}$ & Great Hotels of the World & London, UK & 192434 & 1012 \\
$\mathbf{4 .}$ & Preferred Hotel Group & Chicago, Illinois, USA & 161516 & 843 \\
$\mathbf{5 .}$ & Keytel SA & Barcelona, Spain & 143900 & 1600 \\
$\mathbf{6 .}$ & Magnuson Hotels & Spokane, Washington, USA & 139776 & 1792 \\
$\mathbf{7 .}$ & Supranational Hotels Ltd. & London, UK & 118221 & 986 \\
$\mathbf{8 .}$ & Best Eurasian Hotels Ltd. & Moscow, Russia & 103300 & 929 \\
$\mathbf{9 .}$ & Worldhotels & Frankfurt am Main, Germany & 100926 & 449 \\
$\mathbf{1 0}$ & Associated Luxury Hotels International & Orlando, Florida, USA & 89514 & 139 \\
\hline
\end{tabular}


Table 5. Business models according to the offered services and the level of embeddedness in the host economy. Source: Own elaboration on the basis of León-Darder et al (2011, p. 109, Table 1)

\begin{tabular}{cccccc}
\hline \multirow{2}{*}{ ACTIVITIES \& SERVICES } & \multicolumn{5}{c}{ BUSINESS MODELS } \\
& Owning & Leasing & Managing & Franchising & Consortium \\
\hline Owning the real estate & $\sqrt{ }$ & - & - & - & - \\
Operating the busines & $\sqrt{ }$ & $\sqrt{ }$ & $\sqrt{ }$ & - & - \\
Training staff & $\sqrt{ }$ & $\sqrt{ }$ & $\sqrt{ }$ & $(\sqrt{ })$ \\
Providing a brand & $\sqrt{ }$ & $\sqrt{ }$ & $\sqrt{ }$ & $\sqrt{ }$ & $(\sqrt{ })$ \\
Sales and marketing & $\sqrt{ }$ & $\sqrt{ }$ & $\sqrt{ }$ & \\
\hline & \multicolumn{7}{c}{ Medium commitment } & Low commitment
\end{tabular}

Embeddedness in the host market 
Figure 1. A stylised example of an international hotel group's global production network. Source: Niewiadomski (2011, p. 96, modified)

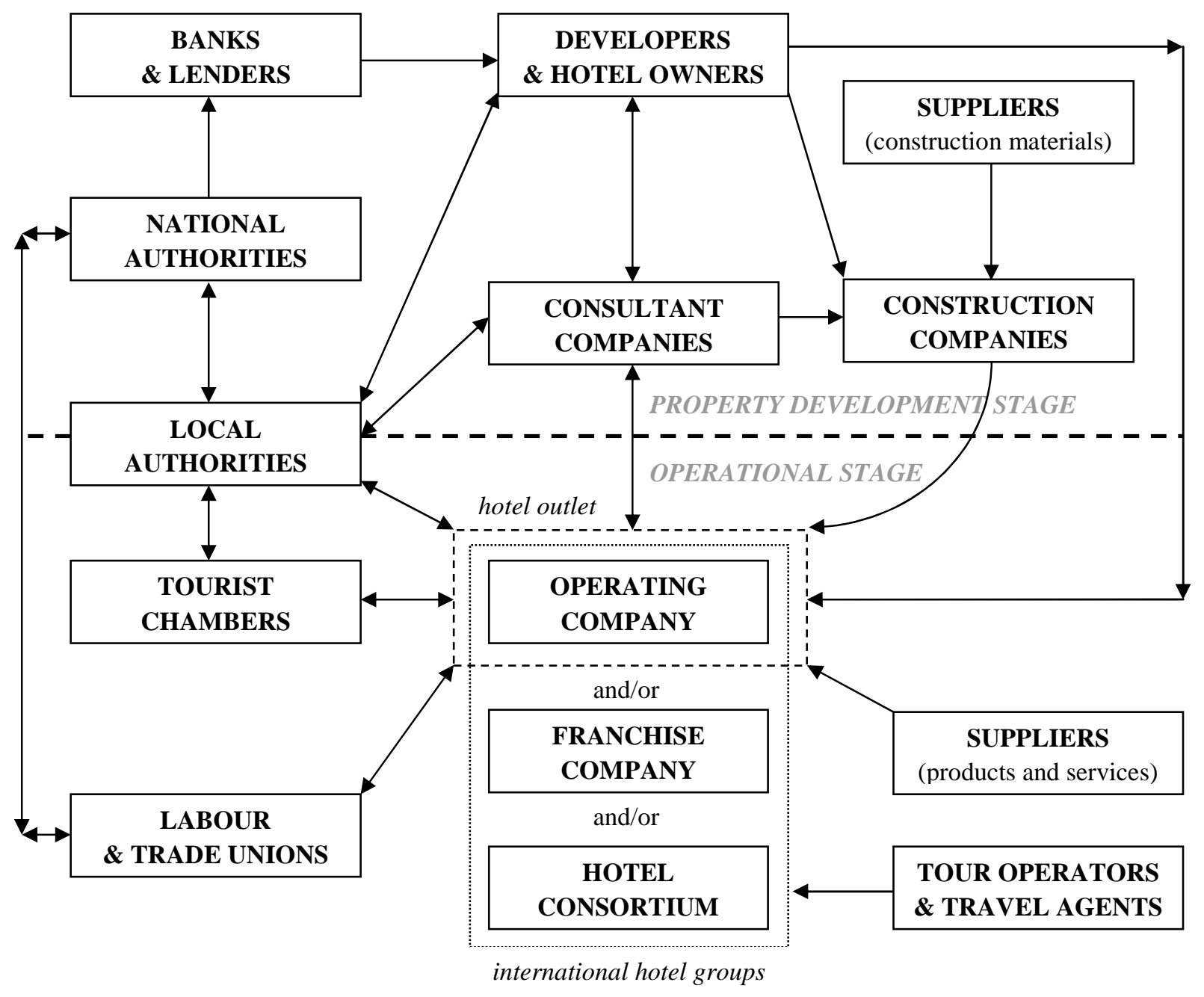

